\title{
Influence of Soil Parameters on the Establishment of Turf Grass Species under Different Methods of Planting
}

\author{
R. Dhanalakshmi ${ }^{1}$, V. Vijaya Bhaksar ${ }^{2}$ and P. Subbaramamma ${ }^{2 *}$ \\ ${ }^{1}$ Department of Floriculture and Landscape Architecture, College of Horticulture, Dr. Y. S. R. \\ Horticultural University, Venkataramannagudem-534 101, West Godavari District, \\ Andhra Pradesh, India \\ ${ }^{2}$ Department of Plant Physiology, College of Horticulture, Dr. Y. S. R. Horticultural \\ University, Venkataramannagudem-534 101, West Godavari District, Andhra Pradesh, India \\ *Corresponding author
}

\section{A B S T R A C T}

The present investigation was carried out at College of Horticulture, V.R. Gudem, West Godavari district of Andhra Pradesh during the year 2014-15. Aim of the experiment was to find out the influence of soil parameters on the establishment of turfgrass species under different methods of establishment. The experiment was laid out in a factorial randomized block design with 4 turf grass species viz., Bermuda grass (Cynodon dactylon), Korean

\section{Keywords}

Bermuda grass, Korean grass, St. Augustine

grass, Centipede grass,

Soil bulk density, Soil

EC, Soil porosity

Article Info

Accepted:

24 February 2018

Available Online:

10 March 2018 grass (Zoysia japonica), St. Augustine grass (Stenotaphrum secundatum) and Centipede grass (Erimochloa ophiuroides) planted with dibbling and turf plastering methods. Based on the results obtained it was observed that soil $\mathrm{pH}$, soil porosity, soil moisture content and bulk density showed non-significant influence on the establishment of turfgrass species planted under different methods in comparison to the initial values recorded at the time of planting. However, soil electrical conductivity (EC) recorded significant influence on the establishment of turfgrass species planted under different methods. Dibbling method of planting recorded significantly highest soil EC $\left(0.09 \mathrm{dS} \mathrm{m} \mathrm{m}^{-1}\right)$ in comparison to turf plastering. Among the turf grass species evaluated Bermuda grass recorded significantly highest soil EC $\left(0.16 \mathrm{dS} \mathrm{m}^{-1}\right)$, whereas, Korean grass recorded significantly lowest soil EC $\left(0.04 \mathrm{dS} \mathrm{m}^{-1}\right)$. The interaction effect between Bermuda grass planted with dibbling method recorded significantly highest soil EC $\left(0.18 \mathrm{dS} \mathrm{m}^{-1}\right)$, whereas, Korean grass planted with turf plastering method recorded significantly lowest soil EC $\left(0.04 \mathrm{dS} \mathrm{m}^{-1}\right)$. The data pertaining to influence of major nutrients $(\mathrm{N}, \mathrm{P}$ and $\mathrm{K})$ on the establishment of turfgrass species under different methods of planting was found non-significant for both individual and their interaction effects.

\section{Introduction}

Climate change is posing many challenges to the living organisms including the survival of human beings. Rapid changes in the climate are considered mainly due to deforestation, industrialization, increased vehicle trafficking, increased urbanization and changes in the lifestyle with increased usage of electronic gadgets which are also emanating lot of 
pollutant gases and radiation into the atmosphere, ultimately leading to certain deleterious effects on the living organisms and the food production system. To reduce the deleterious effects due to increased urbanization and emissions from the vehicles it requires keeping the areas clean and green is one of the best options by developing parks with lot of greenery and turf areas in the urban and peri-urban areas to bring down the pollution. Laying out lawns with different turfgrass species is gaining lot of importance in the newly laid out townships to provide a clean and pleasant environment to the inhabitants of the region. Turfgrass is a monocotyledonous plant belonging to the family Graminae and many of the turfgrass species are considered as weeds, in general. Domestication of these weed grasses have become the valuable turfgrass plants. The value of turf grasses has long been recognized from the pre-historic times, but during the past 100 years the aesthetic value of turfgrass species has gained lot of importance for pleasure purposes as well as establishment of sports grounds.

Lawn is an area where grass is grown as a green carpet for landscapes. Lawn is considered as 'heart of landscape' and it is the basic feature for any type of garden. Having a garden with beautiful lawns even at home is considered as an aesthetic prestige and of course it is the dream of many people. The surge for greenery everywhere has induced the mankind across the world to develop gardens in all the viable pockets of urban open spaces. The gravity of this issue in India has urged from common man to policy makers to develop and establish the gardens accordingly as per the law established i.e., mandatory for the corporate sectors to maintain $33 \%$ greenery around their establishments. It is an established fact that millions of acres of turfgrass on home lawns, commercial landscapes, road sides, parks, athletic fields and golf courses have improved the quality of life by providing open space, recreational facilities and business opportunities thereby enhanced the property value and finally led to the conservation of natural resources. Lawn grasses reduce the problem of mud and also reduce the problem of pollutants like dust, absorb the noise, control the soil erosion, protect the ground water, filter the water, produce lot of oxygen and the comprehensiveness of all these environmental benefits improve our quality of life. Lawn is not only enhances the value and beauty of our lives but also contribute towards the improvement in our physical and mental health because of its great therapeutic value. Lawn apart from the functional value has an excellent play surface and the quality of play has a direct correlation with the turf established in the playing area. The cricket ground standards in India have been elevated by establishing and maintaining a good turf that matches with the standards of international play grounds. Eventually when we understand the scientific attempts and research issues taken up in turf grass in India the answer is deprived. There is a significant demand for scientific and technological advancements with regard to the performance of turfgrass species in different areas including aesthetic display in landscaping sectors and a prompt functional usage in the sports domain have necessitated setting a tone for developing futuristic research modules in turfgrass breeding, production and maintenance. Growth and development of grasses is very much influenced by the physicochemical properties of soil i.e., texture, structure, bulk density, mechanical impendence, aeration, moisture content, temperature and their interactions. Further, the soil type can also greatly influence the dry matter production in lawn grasses. Further, information available on the performance of different types of turfgrass species with regard to early and firm establishment with different lawn laying 
methods is very scanty. Therefore, to generate research evidence on the above aspects, the present investigation is being formulated with the objective to find out the influence of soil parameters on the establishment of turfgrass species planted with different methods.

\section{Materials and Methods}

The present experiment was carried out at College of Horticulture, V. R. Gudem which was situated at $16^{0} 53120$ " North latitude and $81^{0} 27^{\prime} 568^{\prime \prime}$ East longitude at an elevation of $34 \mathrm{~m}$ above mean sea level located in West Godavari district of Andhra Pradesh during the year 2014-2015. Aim of the experiment was to find out influence of soil parameters on the establishment of turfgrass species under different methods of planting. Experimental field was laid out in a Factorial Randomized Block Design (FRBD) with three replications with a net plot size of $3 \mathrm{~m} \times 3 \mathrm{~m}$ by leaving a spacing of $1 \mathrm{~m}$ between the plots and replications. The plots were dug out in a manner to bring the down layer of soil to up and moving the top layer of soil to down to a depth of about $60 \mathrm{~cm}$. Then plots were uniformly levelled with a mixture of sand, red earth, tank silt and compost in 2:1:1:1 ratio. Later soil was drenched with chlorpyriphos @ $2.5 \mathrm{ml} \mathrm{l}^{-1}$ to control white ants before turfgrass planting. Rooted slips of four turfgrass species viz., Bermuda grass (Cynodon dactylon), Korean grass (Zoysia japonica), St. Augustine grass (Stenotaphrum secundatum) and Centipede grass (Erimochloa ophiuroides) were collected from Hortus Consultants (I) Pvt. Ltd, Pune, Maharashtra and planted with dibbling (small pieces of grass roots are dibbled at $10 \mathrm{~cm}$ apart on a fairly levelled ground in zig-zag manner when the soil was wet after irrigation) and turf plastering (turfgrass slips were chopped into small bits of 5-7 cm long. Two baskets of chopped grass pieces were mixed well with one basket each of garden soil and fresh cow dung and also added a shovel full of wood ash along with adequate amount of water to form a thick paste like substance. This mixture was then spread uniformly on the surface of a previously levelled and perfectly wetted ground to a thickness of at least $2.5 \mathrm{~cm}$ and watering was done gently with a rose can) methods. The treatment details were: $\mathrm{T}_{1}$ : Bermuda grass with dibbling method; $\mathrm{T}_{2}$ : Korean grass with dibbling method; $\mathrm{T}_{3}$ : $\mathrm{St}$. Augustine grass with dibbling method; $\mathrm{T}_{4}$ : Centipede grass with dibbling method; $\mathrm{T}_{5}$ : Bermuda grass with plastering/slurry method; $\mathrm{T}_{6}$ : Korean grass with plastering/slurry method; $\mathrm{T}_{7}$ : St. Augustine grass with plastering/slurry method; $\mathrm{T}_{8}$ : Centipede grass with plastering/slurry method. Turfgrass species were provided sufficient moisture by applying water every day through rose can at regular interval to promote germination as early as possible. Hand weeding was carried out regularly at fortnight interval commencing from 30 days after planting to control both annual and perennial weeds during the course of establishment of turfgrass species. Data were collected on various soil parameters during just before planting of turfgrass species and at the end of the experiment i.e., 120 days after planting from five randomly selected places and the composite samples were used for estimation of different soil parameters and calculated the average values. Soil $\mathrm{pH}$ was measured by using potentiometer (Piper, 1966). Weighed $20 \mathrm{~g}$ of soil into a $100 \mathrm{ml}$ beaker then added $40 \mathrm{ml}$ of distilled water and stirred the suspension at regular intervals for about 30 minutes. The $\mathrm{pH}$ meter was calibrated by using acidic and alkaline or neutral $\mathrm{pH}$ buffers. Carefully inserted the combined electrode of $\mathrm{pH}$ meter into 1:2 ratio of soil, water suspension and recorded the soil $\mathrm{pH}$. Electrical conductivity of soil was measured by using Electrical Conductivity meter through conductivity bridge method developed by Jackson (1973). Weighed $20 \mathrm{~g}$ of soil sample into a $100 \mathrm{ml}$ beaker then added 
$40 \mathrm{ml}$ of distilled water and stirred intermittently for one hour. Sample was allowed to stand until a clear supernatant liquid was obtained. Calibrated the conductivity bridge with the help of standard $\mathrm{KCl}$ solution and determined the cell constant. Conductivity of supernatant liquid was measured using the electrode of conductivity meter. The average EC value was expressed in $\mathrm{dSm}^{-1}$. Soil porosity was measured using tension table method as per the procedure explained by Vomocil (1965). Bulk density of soil was measured by core sampler method developed by Blake (1965) (Table 1). Smooth and undisturbed vertical or horizontal soil surface was prepared at a depth to be sampled. Driven the sampler into the soil to a required depth to fill the inner cylinder but not to compress the soil and then carefully removed the sampler to preserve the sample. Two cylinders were separated from one another without disturbing the soil contained in the inner cylinder. Carefully the soil sample was trimmed from each side of the cylinder. The cylinder filled with the soil or the soil from the cylinder was placed into a previously weighed tin $\left(\mathrm{W}_{1}\right)$ and the fresh weight of soil was recorded $\left(\mathrm{W}_{2}\right)$. Later the soil sample was removed and dried in hot air oven at $105^{\circ} \mathrm{C}$. The dry weights of soil samples were recorded $\left(\mathrm{W}_{3}\right)$.

Bulk density $(\mathrm{g} / \mathrm{cc})=\frac{\mathrm{W}_{3}-\mathrm{W}_{2}-\mathrm{W}_{1}}{\text { Volume of cylinder }}$

Soil moisture content was measured by gravimetric method developed by Black (1965). Weighed the aluminium tin and recorded the weight $\left(\mathrm{W}_{1}\right)$. Placed soil sample in the tin and recorded the weight $\left(\mathrm{W}_{2}\right)$. Aluminium tin along with soil sample was placed in the hot air oven at $105^{\circ} \mathrm{C}$ for 24 hours. After 24 hours recorded the dry soil sample along with aluminium tin as $\left(\mathrm{W}_{3}\right)$ and soil moisture content was calculated as per the formula given below.

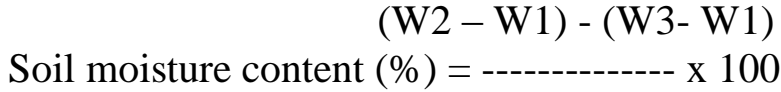

(W3- W1)

Soil samples collected from different locations within the plot by using soil auger were combined together as a composite sample and the final representative soil sample was taken by using quartering method to estimate $\mathrm{N}, \mathrm{P}$ and $\mathrm{K}$ status in the soil. Nitrogen content in the soil was estimated as per the procedure of Modified Kjeldahl Method outlined by Jackson (1973). Phosphorous content in the soil was estimated using Olsen's method as per the procedure outlined by Jackson (1973). Potassium content in the soil was estimated by Flame Photometry method explained by Jackson (1973). The data arrived was analysed statistically by following the standard statistical methods outlined by Panse and Sukhatme (1985).

\section{Results and Discussion}

The data pertaining to influence of soil $\mathrm{pH}$ on the establishment of turfgrass species under different methods of planting was presented in Table 2. The data were found non-significant with regard to individual and combined effects of turfgrass species planted under different methods of planting. The data signifies that soil $\mathrm{pH}$ under normal conditions has little or no influence on the turfgrass species as well as methods of establishment. Nikolaos et al., (2011) reported similar kind of observation while working with the establishment of different turfgrass species.

Data pertaining to soil electrical conductivity (EC) presented in Table 2 showed significant differences in the establishment of turfgrass species planted under different methods. Soil EC was found decreased gradually from the time of planting to the end of the experiment. Dibbling method of planting recorded 
significantly more soil EC $\left(0.09 \mathrm{dS} \mathrm{m}^{-1}\right)$ than turf plastering $\left(0.08 \mathrm{dS} \mathrm{m^{-1 }}\right)$ method of planting. Among the turfgrass species, Bermuda grass recorded significantly highest soil EC $\left(0.16 \mathrm{dS} \mathrm{m}^{-1}\right)$, whereas Korean grass recorded significantly lowest soil EC $(0.04 \mathrm{dS}$ $\left.\mathrm{m}^{-1}\right)$. Observation with regard to a significant reduction in the soil EC from 0.2 to 0.04 with Korean grass might be due to its inherent genotypic character. Further, significant differences were observed in the soil EC between methods of planting and turfgrass species. Bermuda grass planted with dibbling method of planting recorded significantly highest soil EC (0.18), whereas Korean grass planted with turf plastering method recorded significantly lowest soil EC (0.04). The differences in soil EC might be attributed to the inherent genetic character of turfgrass species rather than method of establishment and was found in agreement with the earlier report published by Nikolaos et al., (2011) while working with different turfgrass species. In general, it is thought that soil salinity caused due to deposition of dissolved salts on the surface of soil through the process of evaporation from subsoil. In the present investigation, soil EC was found decreased from the time of planting to 120 days after planting in almost all the treatments which might be attributed to continuous draining-off the excess quantity of water soluble salts from surface of the soil to the deeper layers of the soil due to application of good quality irrigation water at frequent intervals. Chris (2015) has opined that cropping with good drainage system certainly reduces the soil salinity. Further, the present results were in close confirmity with the earlier reports published by Murphy et al., (1993), Carrow et al., (2001) and Green et al., (2001) while experimenting with different turfgrass species.

The data pertaining to influence of soil porosity on the establishment of turfgrass species with different methods of planting was found non-significant (Table 2). However, an increase in the soil porosity was observed at the end of the experiment when compared with the time of planting (38.52\%) in all the individual treatments and their combinations. Pagliai and Vignozzi (2002) reported that soil porosity was found closely related to the physical behaviour of soil for root penetration and water movement in the soil (Sasal et al., 2006). Soils were found made up of with three important constituent particles viz, minerals, organic matter and space (called pore- or voidvolume). The relative proportion of these characters varied with soil type, but pore space could occupy to about half the volume in a medium textured soil. The water content required for optimum plant growth was found approximately half the pore space occupied with water and half the pore space with air. The proportions of water and air could exchange rapidly depending on weather, rate of evapotranspiration (ET) and other factors. The better root penetration of turfgrass species within the pores present in each soil type causes an increase in aeration that leads to an increase in soil porosity which was observed from planting before the experiment to the end of experiment. Ok et al., (2003) reported similar kind of observation while working with turfgrass species.

The data pertaining to influence of soil moisture content on the establishment of turfgrass species with different methods of planting was found significant between the methods of planting, whereas, influence of soil moisture content was found non-significant among the turfgrass species and their interaction effects with methods of planting (Table 2). All the treatments have recorded a slight increase in the soil moisture content at the end of the experiment in comparison to soil moisture content (18.82) estimated before planting. The reason might be attributed to application of irrigation water at frequent intervals and improved water holding capacity of sandy loam soil. 
Table.1 Physical and chemical properties of the soil estimated at the beginning of the experiment

\begin{tabular}{|c|c|c|c|}
\hline S. No. & Properties & $\begin{array}{l}\text { Value } \\
\text { obtained }\end{array}$ & Methods employed \\
\hline $\begin{array}{l}\text { I. } \\
\text { a. }\end{array}$ & $\begin{array}{r}\text { Physical properties: } \\
\text { Particle size analysis } \\
\text { Sand (\%) } \\
\text { Silt (\%) } \\
\text { Clay (\%) } \\
\text { Organic carbon }(\%)\end{array}$ & $\begin{array}{l}70 \% \\
20 \% \\
10 \% \\
0.26 \%\end{array}$ & $\begin{array}{l}\text { International pipette method (Piper, 1966) } \\
\text { Walkley and Black method (1946) }\end{array}$ \\
\hline $\begin{array}{l}\text { II. } \\
\text { a. } \\
\text { b. } \\
\text { c. } \\
\text { d. } \\
\text { e. } \\
\text { f. g. } \\
\text { h. }\end{array}$ & $\begin{array}{l}\text { Chemical properties: } \\
\text { Available Nitrogen } \\
\text { Available } \mathrm{P}_{2} \mathrm{O}_{5} \\
\text { Available } \mathrm{K}_{2} \mathrm{O} \\
\text { Soil pH } \\
\text { Soil EC } \\
\text { Soil porosity } \\
\text { Soil Bulk density } \\
\text { Soil Moisture content }\end{array}$ & $\begin{array}{l}186 \mathrm{~kg} \mathrm{ha}^{-1} \\
32.5 \mathrm{~kg} \mathrm{ha}^{-1} \\
215 \mathrm{~kg} \mathrm{ha}^{-1} \\
6.57 \\
0.2 \mathrm{dS} \mathrm{m} \\
38.52 \% \\
1.69 \mathrm{~g} / \mathrm{cc} \\
18.82 \%\end{array}$ & $\begin{array}{l}\text { Modified Kjeldahl method (Jackson, 1973) } \\
\text { Olsen's method (Jackson, 1967) } \\
\text { Flame photometry (Jackson, 1973) } \\
\text { Potentiometry (Piper, 1966) } \\
\text { Conductivity bridge (Jackson, (1967) } \\
\text { Tension table method (Vomocil, 1965) } \\
\text { Core sampler method (Blake, 1965) } \\
\text { Gravimetric method (Black, 1965) }\end{array}$ \\
\hline
\end{tabular}

Table.2 Influence of soil parameters on the establishment of turfgrass species under different methods of planting

\begin{tabular}{|c|c|c|c|c|c|}
\hline Treatment & Soil pH & $\begin{array}{l}\text { Soil EC } \\
\left(\mathbf{d S m}^{-1}\right)\end{array}$ & $\begin{array}{c}\text { Soil Porosity } \\
(\%)\end{array}$ & $\begin{array}{c}\text { Soil Bulk } \\
\text { Density (g/cc) }\end{array}$ & $\begin{array}{l}\text { Soil Moisture } \\
\text { content }(\%)\end{array}$ \\
\hline \multicolumn{6}{|l|}{ Method of planting } \\
\hline Dibbling $\left(\mathbf{E}_{1}\right)$ & 6.69 & 0.09 & 49.33 & 1.36 & 22.90 \\
\hline Turf plastering $\left(\mathbf{E}_{2}\right)$ & 6.68 & 0.08 & 48.08 & 1.42 & 19.58 \\
\hline & & & & & \\
\hline SEm \pm & 0.01 & 0.001 & 0.79 & 0.02 & 0.36 \\
\hline CD at 5\% & N.S & 0.01 & N.S & N.S & 1.10 \\
\hline \multicolumn{6}{|l|}{ Turfgrass species } \\
\hline Bermuda grass $\left(\mathrm{G}_{1}\right)$ & 6.68 & 0.16 & 50.00 & 1.35 & 22.37 \\
\hline Korean grass $\left(\mathbf{G}_{2}\right)$ & 6.67 & 0.04 & 48.83 & 1.43 & 20.26 \\
\hline St. Augustine grass $\left(\mathbf{G}_{3}\right)$ & 6.69 & 0.07 & 47.66 & 1.38 & 20.79 \\
\hline Centipede grass $\left(\mathrm{G}_{4}\right)$ & 6.69 & 0.05 & 48.66 & 1.41 & 21.53 \\
\hline SEm \pm & 0.01 & 0.002 & 1.11 & 0.03 & 0.52 \\
\hline CD at $5 \%$ & N.S & 0.01 & N.S & N.S & N.S \\
\hline \multicolumn{6}{|c|}{ Method of planting x Turfgrass species } \\
\hline $\mathrm{E}_{1} \times \mathrm{G}_{1}$ & 6.68 & 0.18 & 51.00 & 1.31 & 24.19 \\
\hline$E_{1} \times G_{2}$ & 6.69 & 0.05 & 48.67 & 1.41 & 21.54 \\
\hline $\mathbf{E}_{1} \times \mathbf{G}_{3}$ & 6.69 & 0.08 & 49.00 & 1.35 & 22.24 \\
\hline$E_{1} \times G_{4}$ & 6.70 & 0.05 & 48.67 & 1.40 & 23.64 \\
\hline$E_{2} \times G_{1}$ & 6.68 & 0.15 & 49.00 & 1.41 & 20.56 \\
\hline $\mathrm{E}_{2} \times \mathrm{G}_{2}$ & 6.65 & 0.04 & 49.00 & 1.44 & 18.99 \\
\hline $\mathrm{E}_{2} \times \mathrm{G}_{3}$ & 6.69 & 0.06 & 46.33 & 1.41 & 19.35 \\
\hline $\mathrm{E}_{2} \times \mathrm{G}_{4}$ & 6.70 & 0.07 & 48.00 & 1.42 & 19.43 \\
\hline SEm \pm & 0.01 & 0.003 & 1.50 & 0.04 & 0.72 \\
\hline CD at $5 \%$ & N.S & 0.01 & N.S & N.S & N.S \\
\hline
\end{tabular}


Table.3 Influence of NPK nutrients on the establishment of turfgrass species under different methods of planting

\begin{tabular}{|c|c|c|c|}
\hline Treatments & $\begin{array}{c}\text { Nitrogen } \\
\text { (kg/ha) }\end{array}$ & $\begin{array}{l}\text { Phosphorus } \\
\text { (kg/ha) }\end{array}$ & $\begin{array}{l}\text { Potassium } \\
\text { (kg/ha) }\end{array}$ \\
\hline \multicolumn{4}{|l|}{ Method of planting } \\
\hline Dibbling $\left(\mathbf{M}_{\mathbf{1}}\right)$ & 101.92 & 34.76 & 219.53 \\
\hline Turf plastering $\left(\mathbf{M}_{2}\right)$ & 102.58 & 34.82 & 220.75 \\
\hline SEm \pm & 0.72 & 0.31 & 0.57 \\
\hline CD at $5 \%$ & N.S & N.S & N.S \\
\hline \multicolumn{4}{|l|}{ Turfgrass species } \\
\hline Bermuda grass $\left(\mathbf{G}_{1}\right)$ & 102.50 & 34.40 & 220.17 \\
\hline Korean grass $\left(\mathbf{G}_{2}\right)$ & 103.00 & 35.25 & 220.05 \\
\hline St. Augustine grass $\left(\mathbf{G}_{\mathbf{3}}\right)$ & 102.50 & 34.48 & 220.16 \\
\hline Centipede grass $\left(\mathbf{G}_{4}\right)$ & 101.00 & 35.05 & 220.20 \\
\hline SEm \pm & 1.02 & 0.44 & 0.82 \\
\hline CD at $5 \%$ & N.S & N.S & N.S \\
\hline \multicolumn{4}{|c|}{ Method of planting $\mathbf{x}$ Turfgrass species } \\
\hline $\mathbf{M}_{1} \times \mathbf{G}_{1}$ & 101.00 & 34.33 & 220.00 \\
\hline $\mathrm{M}_{1} \times \mathrm{G}_{2}$ & 103.00 & 35.33 & 220.44 \\
\hline $\mathbf{M}_{1} \times G_{3}$ & 103.00 & 34.33 & 219.33 \\
\hline $\mathbf{M}_{1} \times \mathbf{G}_{4}$ & 100.67 & 35.07 & 218.33 \\
\hline $\mathrm{M}_{2} \times \mathrm{G}_{1}$ & 104.00 & 34.47 & 220.33 \\
\hline $\mathrm{M}_{2} \times \mathrm{G}_{2}$ & 103.00 & 35.17 & 219.67 \\
\hline $\mathbf{M}_{2} \times G_{3}$ & 102.00 & 34.63 & 221.00 \\
\hline $\mathbf{M}_{2} \times G_{4}$ & 101.33 & 35.03 & 222.00 \\
\hline SEm \pm & 1.44 & 0.62 & 1.15 \\
\hline CD at $5 \%$ & N.S & N.S & N.S \\
\hline
\end{tabular}

It is an established fact that for optimum plant growth, approximately half the pore space suppose should be filled with water and half the pore space with air. The present result was found in close conformity to the earlier report published by Nikolaos et al., (2011).

The data pertaining to influence of soil bulk density on the establishment of turfgrass species under different methods of establishment was found non-significant for both individual and their combination of treatments (Table 2). However, a gradual decrease in the soil bulk density was noticed with the passage of the experiment when compared with the time of planting (1.69) (Table 1). Soil bulk density is considered as an indicator for the degree of soil compaction and soil health. In general, soil bulk density affects the water infiltration, root penetration, available soil moisture, soil porosity, availability of nutrients and biological activity of the soil microorganisms which ultimately influence the key soil processes thereby the productivity. Bulk density of the soil depends upon organic matter present in the soil, 
texture of the soil, density of soil minerals (sand, silt and clay) and their arrangement. Bulk density of the soil could be changed by various management practices that affect the soil cover, organic matter, soil structure, compaction and soil porosity. Taylor et al., (1972), Gaussoin et al., (2006), Follis et al., (2008) have expressed similar kind of opinion while working with various turfgrass species.

The data pertaining to influence of major nutrients ( $\mathrm{N}, \mathrm{P}$ and $\mathrm{K}$ ) on the establishment of turfgrass species under different methods of planting was found non-significant for both individual as well as their interactions (Table 3). A gradual decrease was observed in the nitrogen content from the time of planting $(186 \mathrm{~kg} / \mathrm{ha})$ (Table 1$)$ to the end of the experiment i.e., 120 days after planting. Nitrogen is considered as one of the most important mineral nutrients used in higher quantities by turfgrass species. It is an important component in many of the biochemical processes and also acts as a constituent of chlorophyll, amino acids, proteins, enzymes, vitamins and many other materials essential for their proper functioning. Nitrogen is further considered as one of the mobile elements in both soil and plant system. A gradual decrease of nitrogen content in the soil might be attributed to several reasons which include leaching, volatilization and uptake by the plant through its root system.

Changes in the quantity of available phosphorus content in the soil was found almost dismal at the end of the experiment i.e., 120 days after planting in comparison to time of planting. The reason might be due to fixation of phosphorus in the soil. Christians (1996) has opined that shoot and root system of turfgrass species were found not able to absorb phosphorus from the soil which may be due to lack of movement of phosphorus in the soil solution near the vicinity of the root system.
Potassium plays an important role in the plant growth and development and also plays a very crucial role in the stress tolerance. Survival of Bermuda grass species under high temperature conditions was thought mainly due to presence of more potassium accumulation in the plant. In the present investigation, potassium content was found slightly changed at the end of the experiment i.e., 120 days after planting in comparison to the beginning of the experiment. The reason might be due to uptake of more potassium from red sandy loam soils. However, uptake of potassium content in quantum from the soil was found less in comparison to nitrogen uptake by different turf grass species (Table 1).

\section{References}

Black, C.A. 1965. Methods of Soil Analysis: Part - I Physical and mineralogical properties. American Society of Agronomy, Madison, Wisconsin, USA.

Blake, G.R. 1965. Bulk Density. In: Methods of Soil Analysis. Agronomy Journal. 9 (Part 11, C.A. Black, ed.) p. 374-390.

Carrow, R.N., Waddington, D.V. and Rieke, P.E. 2001. Turf grass soil fertility and chemical problems: Assessment and management. Ann Arbor Press, Chelsea, MI.

Chris, A. 2015. Managing saline soils in North Dakota. NDSU Agriculture Communication. 701: 857-882.

Christians, N.E. 1996. Phosphorus nutrition of turf grass. Golf Course Management. 64(2): 54-57.

Follis, C.C., Anderson, S.H., Fresenburg, B.S. and Ervin, E.H. 2008. Evaluation of sand-soil-compost root zones developed for athletic fields. Proc. II $^{\text {nd }}$ International Conference on Turf Grass, Acta Horticulturae. 783.

Gaussoin, R., Shearman, R., Leonard, W., McClellan, T. and Lewis, J. 2006. Soil physical and chemical characteristics of 
aging golf greens. USGA Turf Grass and Environmental Research Online. 5(14): 1-11.

Green, R.L., Wu, L. and Klein, G.J. 2001. Summer cultivation increases field infiltration rates of water and reduces soil electrical conductivity on annual blue grass golf greens. HortScience. 36(4): 776-779.

Jackson, M.L. 1973. Soil chemical analysis. Prentice Hall of India $(P)$ Limited, New Delhi.

Murphy, J.A., Rieke, P.E. and Erickson, A.E. 1993. Coring cultivation of a putting green with hollow and solid tines. Agronomy Journal. 85:1-9.

Nikolaos, N., Panayiotis, A.N. and Glykeria, G. 2011. Evaluation of olive mill waste compost as a soil amendment for Cynodon dactylon turf establishment, growth and anchorage. HortScience. 46(6): 937-945.

Ok, C., Anderson, S.H. and Ervin, E.H. 2003.

Amendments and construction systems for improving performance of sandbased putting greens. Agronomy Journal. 95: 1583-1590.
Pagliai, M. and Vignozzi, N. 2002. Soil pore system as an indicator of soil quality. Advances in Geoecology. 35: 69-80.

Panse, V.G. and Sukhatme, P.V. (Revised by Sukhatme, P.V. and Amble, V.N.) 1985. Statistical Methods for Agricultural Workers. ICAR, New Delhi. p. 187202.

Piper, C.S. 1966. Soil and Plant Analysis. Hans Publishers. Bombay, India. p. 4469.

Sasal, M.C., Andriulo, A.E. and Taboada, M.A. 2006. Soil porosity characteristics and water movement under zero tillage in silty soils in Argentinian Pampas. Soil and Tillage Research. 87: 9-18.

Taylor, H.M., Huck, M.G. and Kleooer, B. 1972. Root development in relation to soil physical conditions, In: D. Hiller, Optimizing the soil physical environment towards greater crop yield. Academic Press, New York. p. 55-77.

Vomocil, J.A. 1965. Porosity in methods of Soil Analysis: Physical and Mineralogical properties, including statistics of measurement and sampling. Agronomy, part-1, No. 9, American Agronomy Society, Madison, WI.

\section{How to cite this article:}

Dhanalakshmi, R., V. Vijaya Bhaksar and Subbaramamma, P. 2018. Influence of Soil Parameters on the Establishment of Turf Grass Species under Different Methods of Planting. Int.J.Curr.Microbiol.App.Sci. 7(03): 2607-2615. doi: https://doi.org/10.20546/ijcmas.2018.703.301 